\title{
Bilateral acute acquired toxoplasmic retinochoroiditis after steroid therapy for hantavirus pulmonary syndrome: case report
}

\author{
Retinite toxoplásmica bilateral adquirida após terapia com corticoesteróide para \\ síndrome pulmonar por hantavírus: relatodecaso
}

\author{
Rubens Camargo Siqueira ${ }^{1}$ \\ Rodrigo Jorge $\mathbf{e}^{2}$ \\ Luiz Tadeu de Moraes Figueiredo ${ }^{3}$
}

\footnotetext{
Trabalho realizado no Departamento de Oftalmologia da Faculdade de Medicina de Catanduva - Catanduva (SP) Brazil e Departamento de Oftalmologia da Faculdade de Medicina da Universidade de São Paulo - USP - Campus Ribeirão Preto (SP) - Brazil.

Doutorado - Filiado à Faculdade de Medicina de Catanduva - FAMECA - Catanduva (SP) - Brasil e à Universidade de São Paulo - USP - Ribeirão Preto (SP) - Brasil

${ }^{2}$ Doutorado - USP - Ribeirão Preto (SP) - Brasil.

Livre Docente - USP - Ribeirão Preto (SP) - Brasil.

Corresponding author: Rubens Camargo Siqueira Av. José Munia, 4500 - São José do Rio Preto (SP) Zip Code 15090-500

E-mail: rubenssiqueira@terra.com.br

Recebido para publicação em 04.05.2006

Última versão recebida em 29.10.2006 Aprovação em 07.11.2006

Nota Editorial: Depois de concluída a análise do artigo sob sigilo editorial e com a anuência do Dr. Haroldo Vieira de Moraes Jr. sobre a divulgação de seu nome como revisor, agradecemos sua participação neste processo.
}

\begin{tabular}{|l|}
\hline ABSTRACT \\
\hline Description of a case of acute acquired ocular toxoplasmosis following \\
hantavirus pulmonary syndrome. A 41-year-old man presenting hanta- \\
virus pulmonary syndrome, confirmed in the laboratory by detection of \\
IgM antibodies to the virus, was submitted to high doses of intravenous \\
corticosteroids for two months. After clinical improvement of hantavirus \\
pulmonary syndrome the patient presented visual loss in both eyes that \\
was secondary to a toxoplasmosis retinitis. The retinitis resolved with \\
anti-toxoplasma therapy. Acquired toxoplasmic retinochoroiditis can \\
occur following steroid therapy for hantavirus pulmonary syndrome.
\end{tabular}

Keywords: Hantavirus pulmonary syndrome/drug therapy; Chorioretinitis/etiology; Retinitis; Adrenal cortex hormones

\section{INTRODUCTION}

In 1993, a previously unknown group of hantaviruses emerged in the Americas as the cause of acute respiratory disease now termed hantavirus pulmonary syndrome (HPS). Hantavirus causing HPS are associated with wild rodent species of the subfamily Sigmodontinae and are transmitted to man by contact or through aerosols of excreta and secretions of infected rodents ${ }^{(1-2)}$. For treatment of HPS, it is recommended to hospitalize the patient in an intensive-care unit, and to perform mechanic ventilation for the pulmonary edema and the capillary leaking syndrome in the lungs leading to respiratory failure. The use of high intravenous doses of corticosteroids has been reported as useful treatment for improvement of respiratory failure.

Toxoplasma gondii is a significant cause of infectious retinitis in humans. In 1973, it was stated that systemic symptoms with acute acquired toxoplasmosis caused ocular involvement in $2-3 \%$ of the affected patients ${ }^{(3)}$. Theses authors also concluded that only $2-3 \%$ of ocular toxoplasmosis was acquired and the majority of cases arose from reactivation of congenital infection. However, a high incidence of acquired infection followed by ocular toxoplasmosis has been observed in southern Brazil suggesting that it might be a more common route of transmission ${ }^{(3-4)}$.

Toxoplasma gondii is a common cause of retinochoroiditis. We report here a patient having bilateral toxoplasmosis retinochoroiditis acquired after use of high doses of corticosteroids for treatment of a hantavirus pulmonary syndrome (HPS). 


\section{CASE REPORT}

A 41-year-old man presented with bilateral visual loss after a two-month period of steroid therapy for respiratory failure secondary to HPS.

On examination, best-corrected visual acuity was 20/400 in the right eye and 20/200 in the left. His intraocular pressures were normal. A mild cellular reaction in the anterior chamber and vitreous was observed by slit-lamp biomicroscopy bilaterally. Fundoscopy evaluation showed retinitis in the posterior poles of both eyes (Figure 1A,1B). Fluorescein angiography demonstrated early hypofluorescence in the area of retinitis. Late phases showed staining and leakage around borders of the lesion (active lesion) (Figure 2A, 2B).

Laboratory studies including fluorescent treponemal antibody-antibody screen (FTA-ABS), Lyme disease, complete blood count (CBC), erythrocyte sedimentation rate (ESR), HIV screening, tuberculosis skin testing (purified protein derivative - PPD), chest x-ray and three sets of blood cultures were performed with normal results. However, the patient showed serum positive IgM $(>0.600)$ and elevated $\operatorname{IgG}(>300$ $\mathrm{IU} / \mathrm{ml}$ ) anti-Toxoplasma gondii. The patient was treated with pyrimethamine, folinic acid, and sulfadiazine for 5 weeks. After treatment the lesions were healing (Figure 3A, 3B) and his vision improved to 20/200 (right eye) and 20/100 (left eye) within 2 months.

\section{DISCUSSION}

This is the first report of acquired toxoplasmosis following HPS. Immunossupression by use of high doses of corticosteroids, probably, played a main role in the development of ocular toxoplasmosis in this patient.

The role of cellular immunodeficiency in recurrent toxoplasmic retinochoroiditis: has been demonstrated six Cynomolgus monkeys (Macaca fascicularis) with healed toxoplasmic lesions of the retina were immunosuppressed by total lymphoid irradiation and Toxoplasma specimens were able to
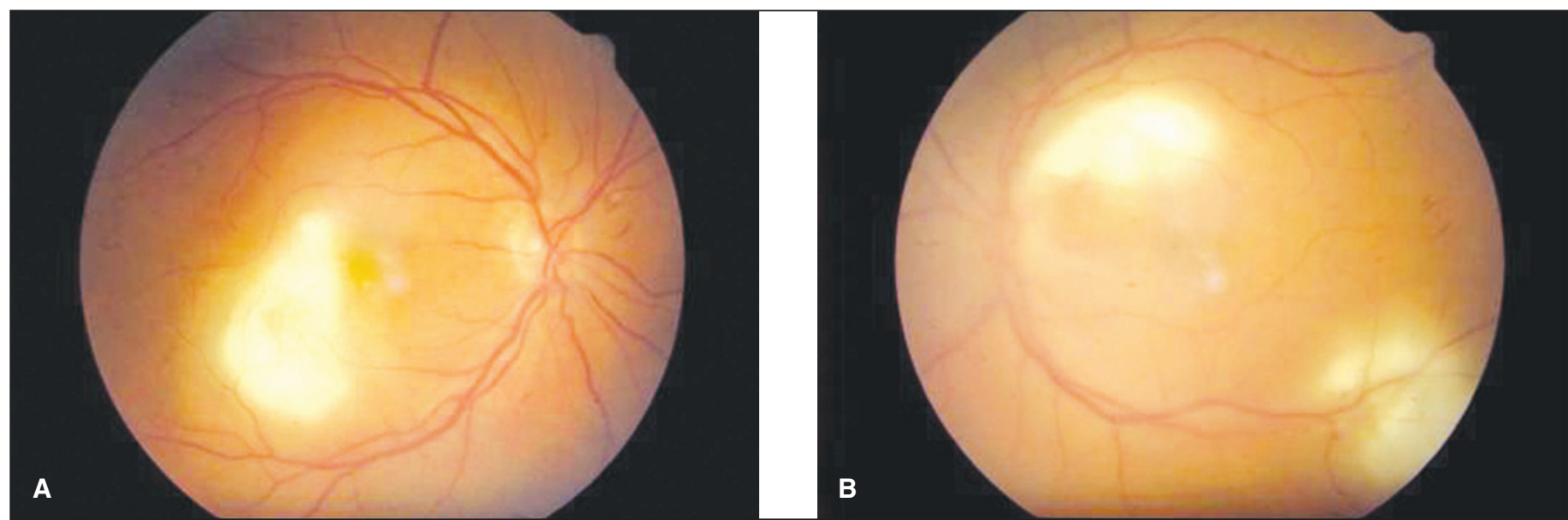

Figure 1 - A e B: Retinitis in posterior poles of both eyes
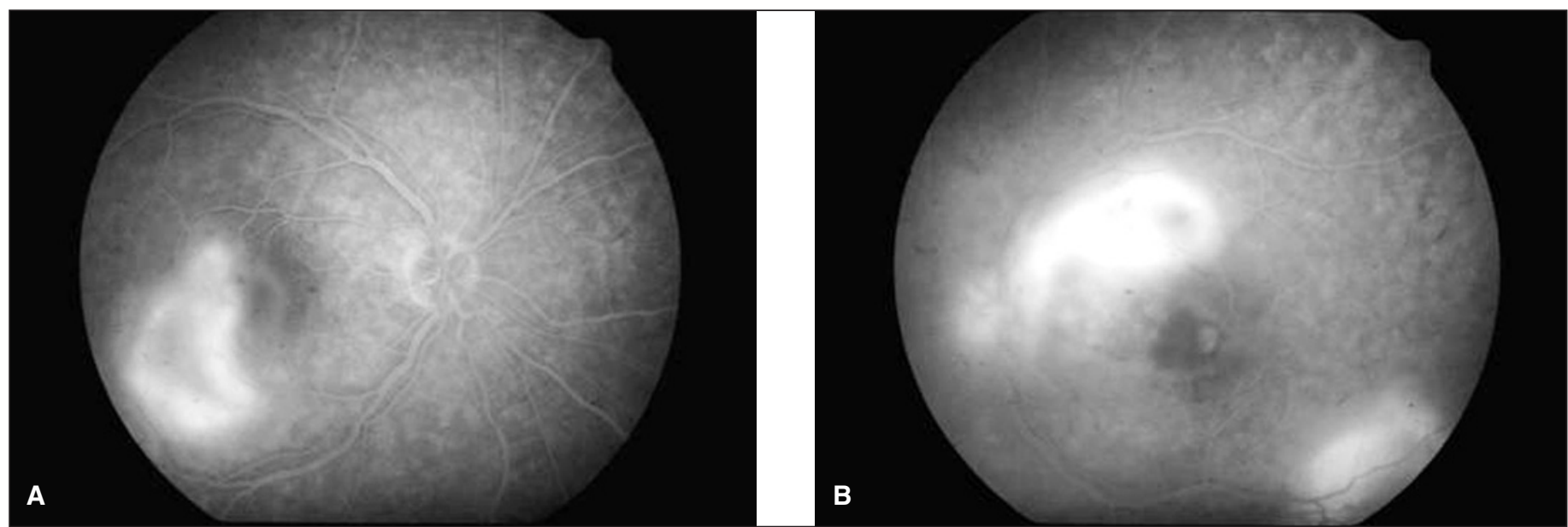

Figure 2 - A e B: Fluorescein angiography showing leakage around borders of lesion (active lesion) 

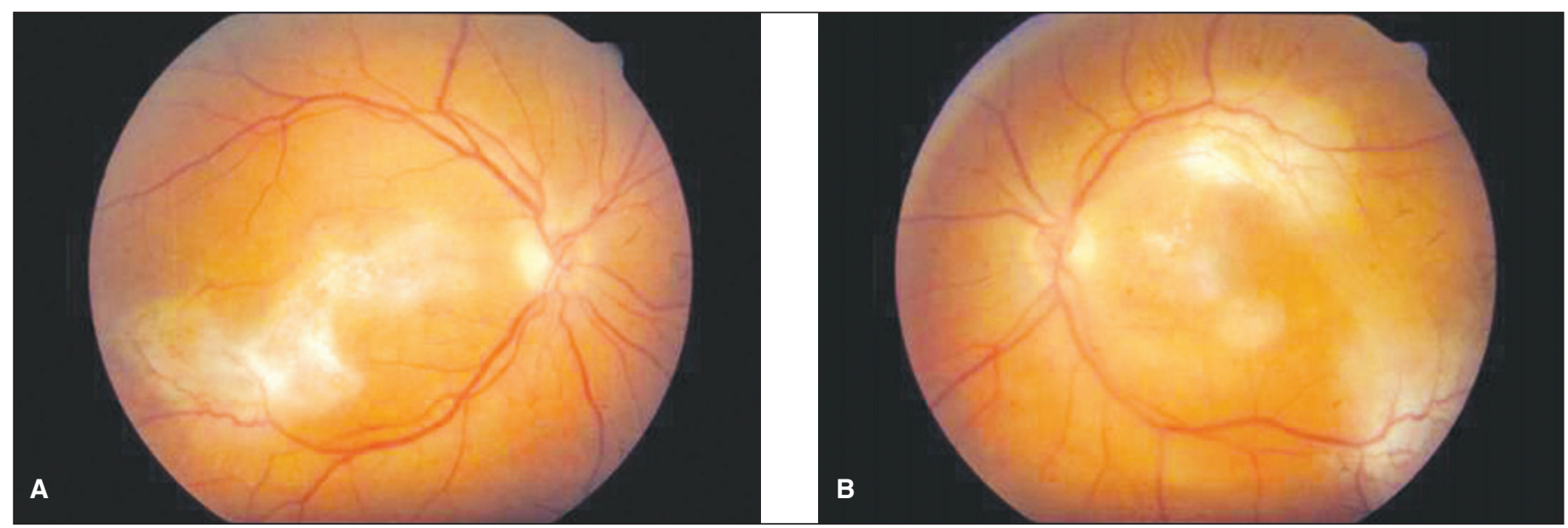

Figure 3 - A e B: After treatment the lesions were healing

proliferate in ocular tissue following the administration of immunosuppressive therapy ${ }^{(5)}$.

A possible relationship between systematic corticosteroid use and reactivation of ocular toxoplasmosis has been discus$\operatorname{sed}^{(6)}$. These authors showed that the disease occurred at intervals of 20 days to approximately 1 year after the start of corticosteroid therapy. Lesions were typical in appearance, course, and manner in which they responded to antimicrobial therapy.

Other authors described a 58-year-old woman who developed ocular toxoplasmosis while receiving long-term systemic corticosteroid therapy allowing correlation of early histopathologic lesions with their clinical counterpart recorded in fundus photographs ${ }^{(7)}$.

Acquired ocular toxoplasmosis has been linked to blood transfusion $^{(7)}$, organ donation ${ }^{(8)}$, breaks in the dermis or contamination of fingers with oocysts ${ }^{(9)}$, ingestion of oocytes from cat feces ${ }^{(10-11)}$, drinking raw milk ${ }^{(12-13)}$, consumption of raw $\operatorname{eggs}^{(14)}$, and ingestion of uncooked or undercooked beef, pork, and lamb ${ }^{(15-18)}$. In one paper, toxoplasmosis was reported in deer and linked to acute illness in humans in three patients.

The case of a 24-year-old man with acquired ocular toxoplasmosis after immunosuppression of tumoral thymic origin has been reported ${ }^{(19)}$.

An article described a 48-year-old woman with a previous a liver transplant and a cataract extraction who developed a necrotizing retinochoroiditis in her right eye. As the retinochoroiditis progressed, visual acuity worsened to the point of no light perception, and the eye became blind and painful. An enucleation was performed and histologic examination showed Toxoplasma gondii necrotizing retinochoroiditis ${ }^{(20)}$.

Hantavirus cardiopulmonary syndrome has been associated with respiratory sequelae related to lung fibrosis. In addition, 2 individuals of 8 we examined 15 and 40 months after HPS, treated in the acute phase with corticosteroids, showed scars of chorioretinitis. One of them had negative serology for toxoplasmosis and the other had IgG antibodies to Toxoplas- $m a^{(21)}$. However, the present study is the first report detecting an acquired toxoplasmosis following HPS.

\section{RESUMO}

Descrição de um caso de toxoplasmose ocular adquirida póssíndrome pulmonar por hantavírus. Paciente com 41 anos do sexo masculino apresentando síndrome pulmonar por hantavírus, confirmado no laboratório pela detecção de anticorpos IGM para o vírus, foi submetido a altas doses de corticosteróides intravenosos durante dois meses. Após melhora clínica da síndrome pulmonar por hantavírus, apresentou perda visual em ambos os olhos secundária a retinite por toxoplasmose confirmada com sorologia (IGG e IGM positivo) A retinite resolveu após terapia sistêmica específica. A retinite por toxoplasmose pode ocorrer após terapia sistêmica com esteróide para síndrome pulmonar por hantavírus.

Descritores: Síndrome pulmonar por hantavírus/quimioterapia; Coriorretinite/etiologia; Retinite; Corticosteróides

\section{REFERENCES}

1. Duchin JS, Koster FT, Peters CJ, Simpson GL, Tempest B, Zaki SR, et al. Hantavirus pulmonary syndrome: a clinical description of 17 patients with a newly recognized disease. The Hantavirus Study Group. N Engl J Med. 1994; 330(14):949-55.

2. Figueiredo LT, Moreli ML, Campos GM, Sousa RL. Hantaviruses in Sao Paulo State, Brazil. Emerg Infect Dis. 2003;9(7):891-2.

3. Perkins ES. Ocular toxoplasmosis. Br J Ophthalmol. 1973;57(1):1-17. Review.

4. Glasner PD, Silveira C, Kruszon-Moran D, Martins MC, Burnier Junior M, Silveira $\mathrm{S}$, et al. An unusually high prevalence of ocular toxoplasmosis in southern Brazil. Am J Ophthalmol. 1992;114(2):136-44.

5. Holland GN, O'Connor GR, Diaz RF, Minasi P, Wara WM. Ocular toxoplasmosis in immunosuppressed nonhuman primates. Invest Ophthalmol Vis Sci. 1988;29(6):835-42.

6. Morhun PJ, Weisz JM, Elias SJ, Holland GN. Recurrent ocular toxoplasmosis in patients treated with systemic corticosteroids. Retina. 1996;16(5):383-7.

7. Nicholson DH, Wolchok EB. Ocular toxoplasmosis in an adult receiving long-term corticosteroid therapy. Arch Ophthalmol. 1976;94(2):248-54.

8. Siegel SE, Lunde MN, Gelderman AH, Halterman RH, Brown JA, Levine AS, 
Graw RG Jr. Transmission of toxoplasmosis by leukocyte transfusion. Blood. 1971;37(4):388-94.

9. Ryning FW, McLeod R, Maddox JC, Hunt S, Remington JS. Probable transmission of Toxoplasma gondii by organ transplantation. Ann Intern Med. 1979;90(1):47-9.

10. Tabbara KF. Ocular toxoplasmosis: toxoplasmic retinochoroiditis. Int Ophthalmol Clin. 1995;35(2):15-29.

11. Frenkel JK, Dubey JP. Toxoplasmosis and its prevention in cats and man. J Infect Dis. 1972;126(6):664-73.

12. Stagno S, Dykes AC, Amos CS, Head RA, Juranek DD, Walls K. An outbreak of toxoplasmosis linked to cats. Pediatrics. 1980;65(4):706-12.

13. Sacks JJ, Roberto RR, Brooks NF. Toxoplasmosis infection associated with raw goat's milk. JAMA. 1982;248(14):1728-32.

14. Riemann HP, Meyer ME, Theis JH, Kelso G, Behymer DE. Toxoplasmosis in an infant fed unpasteurized goat milk. J Pediatr. 1975;87(4):573-6.

15. Jacobs L, Melton ML. Toxoplasmosis in chickens. J Parasitol. 1966;52(6):1158-62.
16. Weinman D, Chandler AH. Toxoplasmosis in man and swine: an investigation of the possible relationship. J Am Med Assoc. 1956;161(3):229-32.

17. Masur H, Jones TC, Lempert JA, Cherubini TD. Outbreak of toxoplasmosis in a family and documentation of acquired retinochoroiditis. Am J Med. 1978; 64(3):396-402.

18. Kean BH, Kimball AC, Christenson WN. An epidemic of acute toxoplasmosis. JAMA. 1969;208(6):1002-4.

19. Figuier P, Saragoussi JJ, Cavaille-Coll M, Le Hoang P, Offret H. [Acquired ocular toxoplasmosis and immunosuppression of tumoral thymic origin]. J Fr Ophtalmol. 1984;7(12):813-7. French.

20. Singer MA, Hagler WS, Grossniklaus HE. Toxoplasma gondii retinochoroiditis after liver transplantation. Retina. 1993;13(1):40-5.

21. Campos GM, Morelli ML, Sousa R, Borges AA, Terra Filho J, Maciel BC, et al. Clinical features and diagnosis of Hantavirus infections in Brazil. In: The $6^{\text {th }}$ International Conference on Hemorrhagic Fever with Renal Syndrome (HFBS) Hantavirus Pulmonary Syndrome (HPS) Hantaviruses Conference Program and Abstracts, 2004. v.1. p.56.

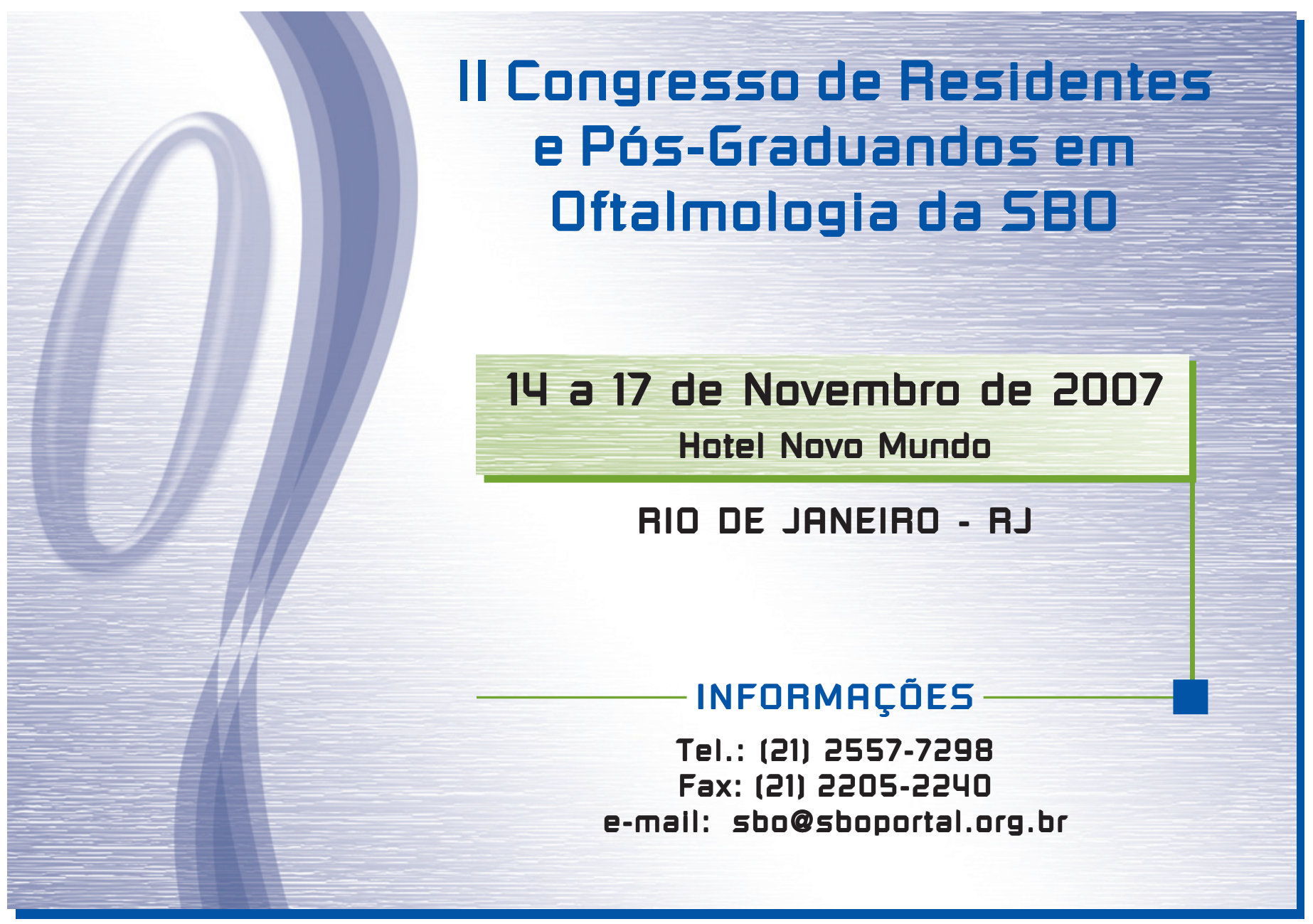

